\title{
STILBINOID COMPOUND FROM ETHANOL EXTRACT OF THE BARK 'RARU', Vatica pauciflora BLUME (DIPTEROCARPACEAE)
}

\author{
R. Kartika ${ }^{1, \bowtie}$, L. Sulastri ${ }^{2}$ and P. Simanjuntak ${ }^{3,4}$ \\ ${ }^{1}$ Faculty of Mathematics and Natural Product, Mulawarman University, Samarinda, Indonesia \\ ${ }^{2}$ Sekolah Tinggi Teknologi dan Farmasi (STTIF), Jalan Kumbang no 23 Bogor 16151, Indonesia; \\ ${ }^{3}$ Research Center for Chemistry, Indonesian Institute of sciences (LIPI), Kawasan Puspiptek \\ Serpong, Kota Tangerang Selatan, Banten, Indonesia; \\ ${ }^{4}$ Faculty of Pharmacy, Pancasila University, Srengseng sawah, Jakarta, Indonesia \\ ${ }^{\circledR}$ Corresponding Author: rudi_biokimia@yahoo.com
}

\begin{abstract}
Vatica pauciflora Blume (local name: Raru) is known by Tapanuli's people widely as additional ingredients mixed to make toddy beverage as tuak which made from nira (sugar palm juice). This addition is intended to match the sweet taste and alcohol. The local people also know raru bark is used as diabetic treatment. In this research, isolation of chemical compound based on cytotoxic treatment with Brine Shrimp Lethality Assay (BSLA) of ethanol extract raru's bark. Separation process was conducted by column chromatography $\left[\left(\mathrm{SiO}_{2} ;\right.\right.$ i. $n$-hexane-ethylacetate $=1: 1 ; i i$. $\mathrm{CHCl}_{3}$ $\mathrm{MeOH}=10: 1 \sim 1: 1$; iii. $\mathrm{CHCl}_{3}-\mathrm{MeOH}-\mathrm{H}_{2} \mathrm{O}=5: 5: 1 ; i v . \mathrm{CHCl}_{3}-\mathrm{MeOH}=1: 1$ and further purification with preparative TLC $\left(\mathrm{SiO}_{2} ; \mathrm{CHCl}_{3}-\mathrm{MeOH}: \mathrm{H}_{2} \mathrm{O}=7: 3: 1\right.$ and gave one pure isolate with $\mathrm{LC}_{50}$ of $34.20 \mathrm{ppm}$. Based on the interpretation of Ultra Violet (UV), FT-Infra Red (FT-IR) and Nuclear Magnetic Resonance $\left({ }^{1} \mathrm{H} \&{ }^{13} \mathrm{C}-\mathrm{NMR}\right)$ spectra show that the compound is a stilbinoid, piceid acid.
\end{abstract}

Keywords: Brine Shrimp Lethality Assay, Indonesian Medicinal Plant, Raru, Stilbinoid, Vatica pauciflora

RASĀYAN J. Chem., Vol. 14, No.1, 2021

\section{INTRODUCTION}

Indonesia is a country rich in biodiversity that can be utilized in all aspects of human life. Traditional medicine is one of the tangible form of utilization of these resources. So far, the people of Indonesia, especially rural communities have been using plants in their environment as traditional medicine. However, at this time in urban communities also tend to choose traditional treatment, because it has been used for generations and made with a simple process known as traditional medicine or herbal medicine. ${ }^{1}$ This is also supported by the economic situation where the price of modern medicines is increasingly expensive and the side effects caused by traditional medicines are relatively smaller compared to synthetic drugs. Therefore, the Indonesian people are even more advanced in developing medicinal plants to be used as traditional medicine as an alternative treatment. ${ }^{2}$ One of the Indonesia medicinal plants that can be used as traditional medicine is "Raru" (local name), Vatica pauciflora Blume (Dipterocarpaceae) that needs to be researched and developed.

This raru plant grows a lot in the forest, including Sumatra and Kalimantan, Indonesia. Part of the bark of this plant in Tapanuli community used as a mixture in a wine drink widely. The addition of raru bark on palm wine will make the palm wine taste sweet and the alcohol is suitable. Most people in Tapanuli also know skin bark raru as a cure for diabetes. ${ }^{3}$ Several studies of chemical compounds of the Vatica spp. plants have been carried out, such as Latip, J. et al (2011) ${ }^{4}$; Kamarozaman. et al. (20013) ${ }^{5}$ has successfully isolated five oligostilbinoids, (-)-trans-resveratrol, (-)-e-viniferin, (-)-laevifonol, (-)-hopeaphenol, (-)vaticanol B, G, $\varepsilon$-viniferin and together with a gallic acid derivative, (-)-bergenin from Vatica oodorata. Keylor et al $(2015)^{6}$, reported that Vatica pauciflora contains many active compounds resveratrol oligomers which useful as anticancer, antioxidants such as pauciflorols A, B and C; isovaticanols B and C; pauciflosides $\mathrm{A}, \mathrm{B}$, and $\mathrm{C}$. 
In previous studies, it was found that some bark extracts from Vatica pauciflora such as $n$-hexane, ethylacetate, ethanol and water extracts have been researched for antioxidant, $\alpha$-glucosidase enzyme inhibitor $^{7}$. The purpose of this research is to know the chemical structure that has cytotoxic properties in ethanol extracts from raru bark (Vatica pauciflora Blume) collected from the Tapanuli region, Indonesia.

\section{Research Materials}

\section{EXPERIMENTAL}

i. $\quad$ Extract of raru's bark (Vatica pauciflora Blume)

ii. Ethylacetate, chloroform, methanol, tlc silica gel $\mathrm{GF}_{254}$ plate, silica gel (60 mesh), sea sand, celite 545, cerium sulfate, $\mathrm{DMSO}, \mathrm{NaCl}(\mathrm{NaCl} 38 \mathrm{~g} / \mathrm{L}$ aquadest), Artemia salina eggs, $\mathrm{KBr}$ discs

\section{Instruments}

UV-Vis spectrophotometer, Fourier Transform-Infrared (FT-IR), Nuclear Magnetic resonance $\left({ }^{1} \mathrm{H}-\&{ }^{13} \mathrm{C}\right.$ NMR) (Jeol NMR, $500 \mathrm{MHz}$ and $125 \mathrm{MHz}$ ) and column chromatography and some glassware.

\section{Isolation and Purification of Ethanol Extract}

Ethanol extracts $(25.0 \mathrm{~g})$ was carried out by column chromatography $\left[\left(\mathrm{SiO}_{2} ; i\right.\right.$. $n$-hexane-ethylacetate $=1$ : 1; ii. $\mathrm{CHCl}_{3}-\mathrm{MeOH}=10: 1 \sim 1: 1$; iii. $\mathrm{CHCl}_{3}-\mathrm{MeOH}-\mathrm{H}_{2} \mathrm{O}=5: 5: 1$ )] giving nine fractions (fr. EtOH-1 fr. EtOH-9) . The Fr. EtOH-7 had the highest cytotoxic properties (5.76 ppm), so it continued second column chromatography $\left(\mathrm{SiO}_{2} ; \mathrm{CHCl}_{3}-\mathrm{MeOH}=1: 1\right)$ gave six fractions (fr. $\mathrm{EtOH}-7-1 \sim$ fr. EtOH-7-6) and fractions 7-4 give the highest cytotoxic among six fractions, with $\mathrm{LC}_{50}$ of $11.94 \mathrm{ppm}$. The fr. EtOH 7-4 was purified with preparative TLC $\left(\mathrm{CHCl}_{3}-\mathrm{MeOH}\right.$ : water $\left.=7: 3: 1\right)$ giving one pure isolate with $\mathrm{LC}_{50}$ of 34.20 ppm.

\section{Identification of Pure Isolate}

Identification of pure isolates based on interpretation of Ultra Violet (UV), Fourier-Transform Infrared (FTIR); ${ }^{1} \mathrm{H}-\&{ }^{13} \mathrm{C}-\mathrm{NMR}$ (Nuclear Magnetic Resonance) and Mass Spectra (LC-MS).

\section{Brine Shrimp Lethality ASSAY (BSLA)}

The cytotoxic activities of extracts and fractions were performed using Brine Shrimp Lethality Assay (BSLA) method described by Sarah et al. $(2017)^{8}$ with slight modification.
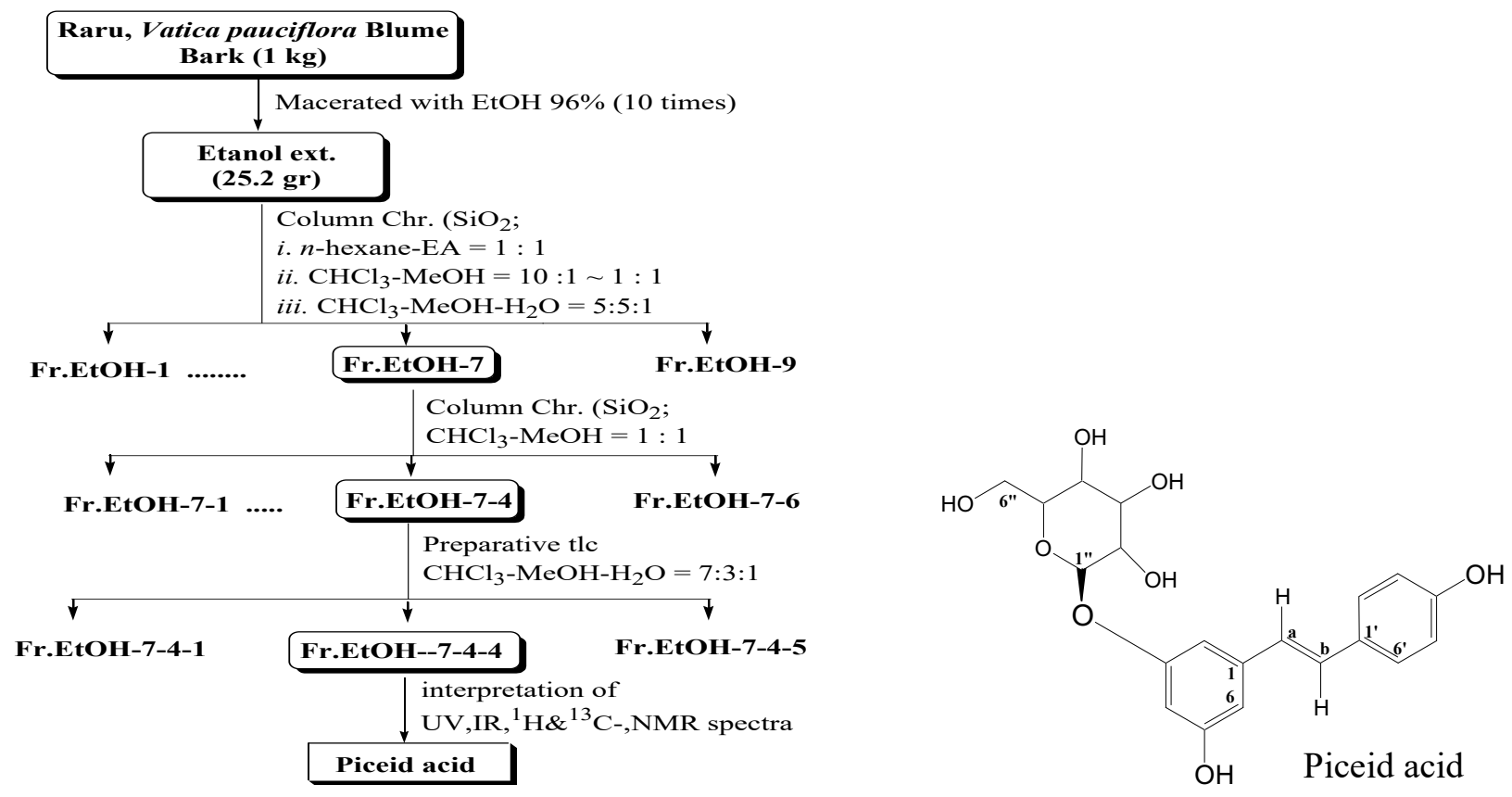

Fig.-1: Scheme of Isolation and Purification Piceid Acid from Ethanol Extract of Bark 'Raru', Vatica pauciflora Blume 
RASĀYAN J. Chem.

Vol. 14 | No. 1 |137-140| January - March | 2021

\section{Characterization of Pure Compound}

\section{RESULTS AND DISCUSSION}

Pure compound (Fr.EtOH-7-4-4) is obtained in the form of a white solid which shows at $m / z 390$ in its mass spectra by LC-MS, which is related to a molecular formula, $\mathrm{C}_{20} \mathrm{H}_{22} \mathrm{O}_{8}$, which can be predicted that the compound is a glycoside derivative of resveratrol. Ultra-violet (UV) spectra indicate that the compound has maximum absorption at $\lambda 267.0$ and $307 \mathrm{~nm}$ indicating the presence of the aromatic group. Infrared (FTIR) spectra shows the presence of hydroxyl, alkene, ether groups in wavenumbers $(v)$ at $3420.79 ; 1916.21$; $1608.25 ; 1518.24 ; 1420.11 ; 968.01 ; 863.09 \mathrm{~cm}^{-1}$. Investigation of ${ }^{1} \mathrm{H}-\mathrm{NMR}$ spectra for pure compound in the high magnetic field region showed the protons at $\delta \mathrm{H} 3.26 \sim 3.88 \mathrm{ppm}$ which showed the presence of oxygenated hydrogen (the presence of hydroxyl groups). There is an anomeric proton signal found at $\delta \mathrm{H}$ $3.70(\mathrm{~m})$. While in the low magnetic field region there are protons that indicate the presence of aromatic and alkene of a pair of doublets at $\delta \mathrm{H} 7.02$ and $7.13(\mathrm{~d}, J=16.5 \mathrm{~Hz})$ which can be confirmed by the presence of monosaccharide of glucose moiety of trans-resveratrol. ${ }^{4} \quad$ Investigation of ${ }^{13} \mathrm{C}$-NMR spectra gave twenty-two carbons, and specifically for carbon glycosides at $\delta \mathrm{C} 102.33 \mathrm{ppm}$ (See Table 1). By comparison, the chemical shifts $(\delta \mathrm{H}$ and $\delta \mathrm{C})$ isolated compound with by research of Chu et al., $(2005)^{9}$ the chemical structure of isolation and purification from the ethanol extract of raru (Vatica pauciflora) was determined as piceid acid (Fig.-2)

Table-1: Comparison of Chemical Shift ${ }^{1} \mathrm{H}-\&{ }^{13} \mathrm{C}-\mathrm{NMR}(\delta \mathrm{H}, \delta \mathrm{C})$ for Fr. EtOH.7-4-4 and Isolated Compounds by Chu et al.,(2005)

\begin{tabular}{|c|c|c|c|c|}
\hline No. & $\begin{array}{l}{ }^{13} \mathrm{C}-\mathrm{NMR} \\
\text { pure comp. }\end{array}$ & ${ }^{13} \mathrm{C}-\mathrm{NMR}{ }^{9)}$ & $\begin{array}{c}{ }^{1} \mathrm{H}-\mathrm{NMR} \\
\text { Pure comp. } \\
(\mathrm{J} \text { in Hz) }\end{array}$ & $\begin{array}{c}{ }^{1} \mathrm{H}-\mathrm{NMR}{ }^{9)} \\
(J \text { in } \mathrm{Hz})\end{array}$ \\
\hline 1 & $139.46(\mathrm{~s})$ & $139.4(\mathrm{~s})$ & - & - \\
\hline 2 & $107.03(d)$ & $107.2(d)$ & $6.75(\mathrm{~s})$ & $6.70(\mathrm{~s})$ \\
\hline 3 & $159.00(\mathrm{~s})$ & $158.9(\mathrm{~s})$ & - & - \\
\hline 4 & $105.01(\mathrm{~d})$ & $104.8(d)$ & $6.39(\mathrm{~s})$ & $6.31(\mathrm{~s})$ \\
\hline 5 & $156.92(\mathrm{~s})$ & $158.3(\mathrm{~s})$ & - & - \\
\hline 6 & $109.61(\mathrm{~d})$ & $109.3(\mathrm{~d})$ & $6.58(\mathrm{~s})$ & $6.54(\mathrm{~s})$ \\
\hline A & $129.12(\mathrm{~d})$ & $128.0(\mathrm{~d})$ & $7.02(\mathrm{~d}, J=16.5)$ & $6.84(\mathrm{~d}, J=16.4)$ \\
\hline $\mathrm{B}$ & $126.20(\mathrm{~d})$ & $125.2(\mathrm{~d})$ & $7.13(\mathrm{~d}, J=16.5)$ & $7,28(\mathrm{~d}, J=16.4)$ \\
\hline 1 ' & $130.02(\mathrm{~s})$ & $128.6(\mathrm{~s})$ & - & - \\
\hline $2{ }^{\prime}$ & $128.09(\mathrm{~d})$ & $127.9(\mathrm{~d})$ & $7.41(\mathrm{~d})$ & $7.38(\mathrm{~d})$ \\
\hline $3^{\prime}$ & $116.52(d)$ & $115.5(\mathrm{~d})$ & $6.76(d)$ & $6.74(\mathrm{~d})$ \\
\hline $4 '$ & $157.67(\mathrm{~s})$ & $157.3(\mathrm{~s})$ & - & - \\
\hline 5 & $116.52(d)$ & $115.5(\mathrm{~d})$ & $6.76(d)$ & $6.74(d)$ \\
\hline $6^{\prime}$ & $128.09(\mathrm{~d})$ & $127.9(\mathrm{~d})$ & $7.42(\mathrm{~d})$ & $7.38(d)$ \\
\hline $1 "$ & $103.22(d)$ & $102.8(\mathrm{~d})$ & $3.70(\mathrm{~m})$ & $3.70(\mathrm{~m})$ \\
\hline $2 "$ & $73.49(\mathrm{~d})$ & $73.3(\mathrm{~d})$ & $3.26 \sim 3.88(\mathrm{~m})$ & $3.16 \sim 3.70(\mathrm{~m})$ \\
\hline 3" & $77.24(\mathrm{~d})$ & $77.1(\mathrm{~d})$ & $3.26 \sim 3.88(\mathrm{~m})$ & $3.16 \sim 3.70(\mathrm{~m})$ \\
\hline 4" & $70.02(d)$ & $69.8(\mathrm{~d})$ & $3.26 \sim 3.88(\mathrm{~m})$ & $3.16 \sim 3.70(\mathrm{~m})$ \\
\hline $5 "$ & $77.00(\mathrm{~d})$ & $76.7(\mathrm{~d})$ & $3.26 \sim 3.88(\mathrm{~m})$ & $3.16 \sim 3.70(\mathrm{~m})$ \\
\hline 6" & $61.12(\mathrm{t})$ & $60.8(\mathrm{t})$ & $3.26 \sim 3.88(\mathrm{~m})$ & $3.16 \sim 3.70(\mathrm{~m})$ \\
\hline
\end{tabular}

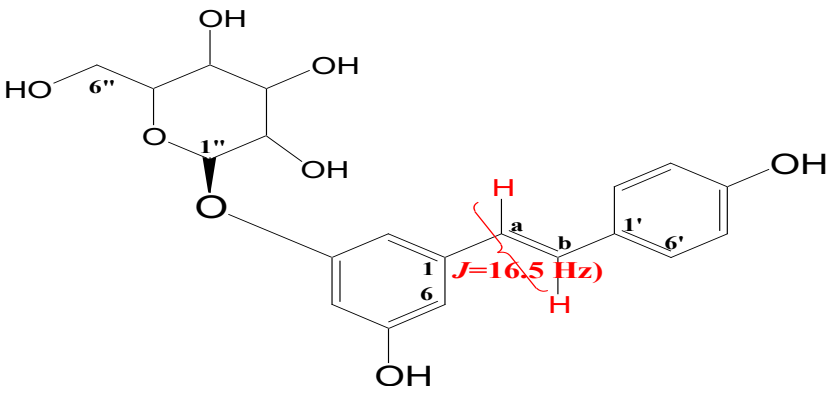

Fig.-2: Chemical Structure for Isolate of Fr. EtOH-7-4-4 (Piceid acid) 
RASĀYAN J. Chem.

Vol. 14 | No. 1 |137-140| January - March | 2021

\section{Brine Shrimp Lethality Assay (BSLA)}

Cytotoxic test by BSLT method for all fractions of the first column chromatography (nine fractions), the second column (six fractions) and preparative tlc (two fractions) can be seen in Table-2.

Table-2: Cytotoxicity for All Fractions and Isolated Compound by the BSLT Method

\begin{tabular}{c|c|c}
\hline No. & Fraction & $\begin{array}{c}\text { LC } 50 \\
\text { (ppm) }\end{array}$ \\
\hline 1 & EtOH-1 & 299.50 \\
\hline 2 & EtOH-2 & 159.15 \\
\hline 3 & EtOH-3 & 595.85 \\
\hline 4 & EtOH-4 & 475,67 \\
\hline 5 & EtOH-5 & 27.77 \\
\hline 6 & EtOH-6 & 17.97 \\
\hline 7 & EtOH-7 & 5.76 \\
\hline 8 & EtOH-8 & 86.09 \\
\hline 9 & EtOH-9 & 110.15 \\
\hline 10 & EtOH-7-1 & 233.61 \\
\hline 11 & EtOH-7-2 & 269.00 \\
\hline 12 & EtOH-7-3 & 334.52 \\
\hline 13 & EtOH-7-4 & 11.94 \\
\hline 14 & EtOH-7-5 & 40.08 \\
\hline 15 & EtOH-7-6 & 19.61 \\
\hline 16 & EtOH-7-4-1 & 38.93 \\
\hline 17 & EtOH-7-4-2 & 13.95 \\
\hline 18 & EtOH-7-4-1 & 38.93 \\
\hline 19 & EtOH-7-4-2 & 13.95 \\
\hline
\end{tabular}

CONCLUSION

One stilbinoid compound, piceid acid from the Indonesian medicinal plant "Raru", Vatica pauciflora Blume has been isolated and identified which has a cytotoxicity against Artemia salina of $13.95 \mathrm{ppm}$.

\section{REFERENCES}

1. A.N. Welz, A. Emberger-Klein, K. BMC Complementary and Therapies, 18, 92(2018), DOI:10.1186/s12906-018-2160-6

2. S.M.A. Aziz, A. Aeron, T.A. Kahil, Health Benefit and Possible Risks of Herbal Medicine, In Book : Microbes in Food and Health (Ed.Neelam Garg, Shadia Abdel Aziz, Abhinav Aeron), Publisher: Springer International Publishing, (2016), DOI:10.1007/978-3-319-25277-3_6

3. S. Ikegami, Annual Report of the University of Shizuoka, Hamamatsu College, No.11-3, Part 5(1997)

4. J. Z. Latip, W.Z.W.M, Ahmat, N., Yamin, B.M., Yusof, N.I.N, Syah, Y.M., Achmad, S.A. Vatica odorata, Australian Journal of Basic and Applied Sciences, 5(96), 113(2011).

5. A.S. Kamarozaman, J. Latip, Y.M. Syah, N. Rajab, A. Jaloh, Journal of Physics, Conferences Series, 423, 1(2013), DOI:10.1088/1742-6596/423/1/012045

6. M.H. Keylor, B.S. Matsuura, C.R.J. Stephenson. Chemistry and Biology of Resveratrol-derived Natural Products. Chem. Rev. 115, 8976-9027 (2015), DOI:1021/cr500689b

7. I.D. Riris, T. Barus, W. Wirjosentono, P. Simanjuntak, Prosiding Seminar Nasional Kimia, pp.375- 83 (2013)

8. Q.S. Sarah, F.C. Anny, M. Misbahuddin, Bangladesh Journal of Pharmacology, 12, 186(2017), DOI: 10.3329/bjp.v12i2.32796

9. X. Chu, A. Sun, R. Liu, Journal of Chromatography A, 1097, 33(2005), DOI:10.1016/j.chroma.2005.08.008

[RJC-6053/2020] 